\title{
PELATIHAN PEMASARAN DIGITAL PRODUK DESA NADUNG: KOPI TEH PELAWAN DAN GULA KABUNG
}

\author{
Eka Rachma Kurniasi*1, Rilia Ayuni ${ }^{2}$, Bima Putra Dewa ${ }^{3}$, Minarti $^{4}$, Meliani ${ }^{5}$, Ridho \\ Pramadhani $^{6}$, Pitri Yanti ${ }^{7}$, Dina Zuhriyyah ${ }^{8}$, Julaiman Alaimusalam ${ }^{9}$, Eni Artika Sari ${ }^{10}$, \\ Revaldy ${ }^{11}$ \\ 1,2,3,4,5,6,7,8,9,10,11 Universitas Muhammadiyah Bangka Belitung \\ *e-mail: eka.rachmakurniasi@ stkipmbb.ac.id ${ }^{1}$, ayunirilia@ gmail.com ${ }^{2}$, bimaputranayu@ gmail.com ${ }^{3}$, \\ minartim30@gmail.com ${ }^{4}$, melianioppo3@gmail.com ${ }^{5}$, ridhopramadhani@gmail.com ${ }^{6}$, \\ pitriyanti422@gmail.com ${ }^{7}$, dinazuhriyyah9@gmail.com ${ }^{8}$, julaiman76@gmail.com ${ }^{9}$, \\ eniartikas@gmail.com ${ }^{10}$, revaldymuhammad657@ gmail.com ${ }^{11}$
}

\begin{abstract}
Abstrak
Pertumbuhan ekonomi suatu daerah sangat mendukung kualitas usaha yang ada di suatu daerah tersebut. Usaha yang dapat menopang ekonomi daerah tersebut salah satunya adalah usaha produksi kopi teh pelawan dan gula kabung. Produk ini merupakan salah satu produk herbal terletak di Desa Nadung Kecamatan Payung Kabupaten Bangka Selatan. Permasalahan yang dihadapi oleh produsen kopi teh pelawan dan gula kabung adalah kesulitan dalam pemasaran produk yang dihasilkan. Hal ini menyebabkan sedikit yang mengetahui keberadaan produk yang di hasilkan sehingga kecil kemungkinan produk laku terjual. Metode pelatihan dilakukan dengan beberapa tahapan dimulai dari perencanaan, pelaksanaan dan evaluasi.Hasil kegiatan pelatihan pemasaran digital dapat meningkatkan pengetahuan produsen kopi teh pelawan dan gula kabung terkait pemanfaatan media sosial melalui aplikasi Instagram dan facebook untuk membantu produsen dalam memasarkan produk secara digital atau online sehingga dapat dikenal oleh masyarakat luas.
\end{abstract}

Kata kunci: Pelatihan, Pemasaran Digital, Kopi Teh Pelawan, Gula Kabung/Aren.

\section{Abstract}

The economic growth of a region greatly supports the quality of existing businesses in that area. One of the businesses that can support the regional economy is the production of coffee, tea, pelawan and sugar. This product is one of the herbal products located in Nadung Village, Payung District, South Bangka Regency. The problem faced by producers of Pelawan tea coffee and sugar bag is the difficulty in marketing the products produced. This causes few to know about the existence of the product being produced so that it is unlikely that the product will be sold. The training method is carried out in several stages starting from planning, implementation and evaluation. The results of digital marketing training activities can increase the knowledge of Pelawan tea coffee producers and sugars related to the use of social media through the Instagram and Facebook applications to help producers market products digitally or online so that they can be known by the wider community.

Keywords: Training, Digital Marketing, Pelawan Tea Coffee, Palm Sugar. 


\section{PENDAHULUAN}

Pelatihan merupakan serangkaian aktivitas individu dalam meningkatkan keahlian dan pengetahuan secara sistematis sehingga mampu memiliki kinerja yang profesional di bidangnya. Tujuan pelatihan untuk meningkatkan produktivitas, kualitas, mendukung perencanaan SDM, meningkatkan moral anggota, memberikan kompensasi yang tidak langsung, meningkatkan keselamatan dan kesehatan kinerja, mencegah kadaluarsa kemampuan dan pengetahuan personal, meningkatkan perkembangan kemampuan dan keahlian personal (Widodo, 2015). Lima (5) prinsip pelatihan menurut Sofiyandi (2013) sebagai berikut:

a. Dalam pelaksanaan pelatihan para peserta harus ikut aktif karena dengan partisipasi peserta akan lebih cepat menguasai dan mengetahui berbagai materi yang diberikan adalah participation.

b. Saling berhubungan sebagai contoh para peserta pelatihan terlebih dahulu diberikan penjelasan secara umum tentang pekerjaan sebelum mereka mempelajari hal-hal khusus dari pekerjaan tersebut adalah Relevance.

c. Program pelatihan harus disesuaikan dengan kebutuhan-kebutuhan yang nantinya akan dihadapi dalam pekerjaan yang sebenarnya adalah Transference.

d. Senantiasa dilakukan secara berulang karena peserta akan lebih cepat untuk memenuhi dan mengingat apa yang telah diberikan adalah Repetition.

e. Setiap program pelatihan yang dilaksanakan selalu dibutuhkan umpan balik yaitu untuk mengukur sejauh mana keberhasilan dari program pelatihan tersebut adalah Feedback.

Pemasaran merupakan mengidentifikasi dan memenuhi kebutuhan manusia dan sosial. Salah satu definisi yang baik dan singkat dari pemasaran adalah memenuhi kebutuhan dengan cara yang menguntungkan menurut Kotler and Keller (2012). Pemasaran digital adalah salah satu media pemasaran yang kini sedang banyak diminati oleh masyarakat dalam mendukung banyak kegiatan (Pradiani, 2017). Manfaat dari pemasaran digital yaitu kecepatan penyebaran produk, kemudahan evaluasi, dan jangkauan lebih luas. Selain itu pemasaran digital memiliki keuntungan dan kelemahan menurut (Markerter, 2017) antara lain keuntungan pemasaran digital yaitu dapat menghubungkan produsen dengan konsumen melalui internet, mendapatkan penghasilan penjualan lebih tinggi dikarenakan semakin sempit jarak dan 
waktu, biaya yang dikeluarkan jauh lebih hemat, pemasaran digital membuat penjual bisa memberikan pelayanan real-time, menghubungkan penjual dengan pelanggan melalui perangkat mobile dimana saja dan kapan saja, serta mampu memberikan kestabilan bagi brand di mata konsumen dari brand lain sebagai pesaing. Adapun kelemahan pemasaran digital diantaranya konsep pemasaran online dapat mudah ditiru, memunculkan banyak pesaing dikarenakan tidak ada batasan teoriti bagi yang dapat menghambat perusahaan dalam memasarkan produknya, pemasaran digital terlalu bergantung dengan teknologi, jika ada reaksi balik yang negatif dari konsumen yang muncul di internet, dapat merusak reputasi perusahaan secara cepat, serta berbagai produk belum tentu cocok jika dipasarkan melalui media online.

Menurut Kotler dan Armstrong (2012) mengatakan bahwa produk adalah segala sesuatu yang dapat ditawar ke pasar untuk memenuhi keinginan atau kebutuhan, termasuk barang fisik, jasa, pengalaman, peristiwa, orang tempat, properti, organisasi, informasi dan ide-ide. Produk memiliki atribut dalam pemasaran diantaranya kualitas produk, fitur produk, gaya dan desain produk, penetapan merek, kemasan, label, dan pelayanan pendukung produk.

Kopi teh pelawan merupakan salah satu produk yang memiliki khasiat bagi kesehatan. kopi pelawan asal Desa Nadung di namai dengan kuped pelawan. Sedangkan teh pelawan di namai dengan repana. Terbentuknya nama produk tersebut berasal dari dari nama keluarga.

Gula kabung merupakan sebutan oleh masyarakat lokal Desa Nadung.Gula kabung merupakan gula asli desa Nadung yang dapat dimanfaatkan sebagai bahan makanan.Berdasarkan hasil wawancara dengan Bapak Mulyadi seorang pembuat gula kabung di desa Nadung, diketahui bahwa gula kabung diambil dari pohon yang ditumbuh dihutan. Pohon gula kabung ini tidak tersedia dengan jumlah yang banyak. Proses budaya pohon gula kabung inilah yang menjadikan jumlah terbatas. Pohon gula kabung tumbuh karena proses alami.Hanya terdapat 1 petani gula kabung yang berdomisili di desa Nadung. Mereka meneruskan usaha gula kabung karena telah menjadi sumber pencarian keluarga turun menurun. Perlu keahlian khusus yang tidak dimiliki banyak orang dalam menyadap air dari kabung.

Desa Nadung merupakan salah satu wilayah yang memiliki tanaman kabung dan pohon pelawan sehingga hal ini mendorong masyarakat Desa Nadung untuk mengelolah tanaman tersebut menjadi suatu produk yang memiliki banyak manfaat dalam kehidupan 
sehari-hari. Akan tetapi banyaknya kendala yang dihadapi oleh produsen dalam memasarkan produk yang dihasilkan. Desa Nadung menjadi salah satu produksi kopi teh pelawan dan gula kabung pada tahun 2016 dan 1997. Pada pembuatan kopi teh pelawan dengan memanfaatkan pucuk dari pohon pelawan. Kopi teh pelawan memiliki khasiat bagi kesehatan manusia, baik dari berbagai penyakit dan perawatan kecantikan. Sedangkan gula kabung diproduksi dari penyadapan air kabung. Manfaat dari gula kabung yaitu dapat diolah menjadi bahan dasar pembuatan bahan masakan dan gula kabung mengandung jumlah kalori yang tepat, zat besi yang tinggi, dan niacen. Kopi teh pelawan dan gula kabung yang dihasilkan dari pengelolaan pucuk pelawan dan air kabung sangat dapat membantu dalam menambah penghasilan masyarakat. Dalam memproduksi kopi teh pelawan dan gula kabung produsen keterbatasan pengetahuan dalam pembuatan media promosi yang menarik.

Pandemi covid-19 yang menyebar sampai saat ini mempengaruhi sisi kehidupan manusia baik pendidikan, ekonomi dan sebagainya. Covid-19 ini menghambat aktivitas masyarakat (Nadhira Salsabila, 2020). Pemerintah mengambil kebijakan terkait aktivitas manusia sehari-hari yang semula dilakukan dengan tatap muka dan berubah menjadi online baik itu dalam pendidikan dan lainnya. hal ini dihimbau oleh pemerintah agar bekerja, belajar dan beribadah di rumah. Dengan demikian, pandemi covid-19 ini sangat mempengaruhi perekonomian manusia sehingga mengalami kendala baik dalam jual beli produk. Dalam hal ini dialami oleh produsen kopi teh pelawan dan gula kabung Desa Nadung mengalami kendala dalam pemasaran produk yang hanya dari mulut ke mulut. Oleh karena itu, dengan adanya pelatihan pemasaran digital dapat membantu produsen mempromosikan produk melalui media sosial menggunakan aplikasi Instagram dan facebook. pemasaran digital membantu produsen mempromosikan produk secara online tanpa harus bertatap muka. Pemanfaatan media sosial merupakan solusi yang sangat tepat

Permasalahan yang dihadapi oleh produsen kopi teh pelawan dan gula kabung adalah kesulitan dalam pemasaran produk yang dihasilkan. Selain itu permasalahan yang dihadapi produsen yaitu proses pemasaran yang dilakukan saat ini masih sangat terbatas pada promosi dari mulut ke mulut. Keterbatasan pengetahuan produsen terhadap pemanfaatan teknologi dalam membantu pemasaran produk sehingga kurangnya pengetahuan produsen terhadap teknik pemasaran dengan tujuan untuk meningkatkan jumlah penjualan produk kopi teh 
pelawan dan gula kabung yang dihasilkan melalui media internet dan belum adanya melakukan media promosi produk yang dimiliki produsen.

Berdasarkan latar belakang tersebut, perlu dilakukan pelatihan pemasaran digital produk Desa Nadung : kopi teh pelawan dan gula kabung bagi produsen kopi teh pelawan dan gula kabung. Pelatihan yang dilakukan diharapkan dapat membantu dalam pemasaran produk yang dihasilkan secara digital melalui aplikasi facebookdan instagramsehingga kopi teh pelawan dan gula kabung dapat dikenal oleh masyarakat luas.

\section{METODE}

Pelatihan pemasaran digital produk lokal Desa Nadung diikuti sebanyak dua produsen kopi dan teh pelawan serta satu orang produsen gula kabung. Pelatihan dilaksanakan secara tatap muka di Gedung Serba Guna Desa Nadung dengan tetap mematuhi protokol kesehatan. Pelatihan diawali dengan penjelasan mengenai pengertian pemasaran digital dan manfaatnya bagi masyarakat khususnya produsen kopi teh pelawan dan gula kabung. Kemudian dilanjutkan dengan materi tentang langkah-langkah memasarkan produk secara digital melalui media sosial facebook dan instagram dan dilanjutkan dengan pengelolaan akun media sosial yang telah dibuat serta strategi dalam memasarkan produk.

Akun facebook dan instagram yang telah dibuat sebelumnya memuat nama akun, produk yang dijual, dan narahubung. Pengelolaan media sosial dimulai dengan mengupload logo dan membuat deskripsi produk yang akan dijual dan lainnya. Adapun tahapan pelatihan pemasaran digital produk Desa Nadung berupa kopi teh pelawan dan gula kabung adalah sebagai berikut:

1. Perencanaan

Perencanaan dilakukan dalam memenuhi kebutuhan yang diperlukan untuk memudahkan penyampaian informasi. Langkah pertama yaitu menentukan media sosial yang digunakan untuk memasarkan produk dan membuat akunnya, kemudian menentukan jadwal pelatihan dan merumuskan materi yang akan disampaikan saat pelatihan serta memenuhi kelengkapan yang diperlukan selama pelatihan.

2. Pelaksanaan

Pelatihan dilaksanakan selama satu hari di Gedung Serba Guna Desa Nadung pada tanggal 19 Februari 2021. Mengedukasi produsen dan memahami cara mengelola 
media sosial facebook dan instagram untuk memasarkan produk menjadi tujuan penting dalam pelatihan ini.

3. Evaluasi

Evaluasi dilakukan terhadap produsen kopi teh pelawan dan gula kabung yang telah mengikuti pelatihan. Pre-test diberikan kepada peserta sebelum pelatihan dimulai untuk mengetahui pemahaman awal terhadap materi pelatihan. Setelah pelatihan selesai, peserta diberikan post-test dengan soal yang sama untuk mengetahui pemahaman peserta terhadap materi pelatihan pemasaran digital produk Desa Nadung yang telah diberikan oleh pemateri.

\section{HASIL DAN PEMBAHASAN}

Pelaksanaan pelatihan pemasaran digital produk lokal desa nadung bagi produsen kopi teh pelawan dan gula kabung telah sukses dilaksanakan. Pelatihan dilaksanakan untuk memberikan pengetahuan dan selama satu hari pada tanggal 19 febuari 2021 dengan tujuan untuk memberikan pemahaman kepada produsen kopi teh pelawan dan gula kabung mengenai tata cara pemasaran yang dilakukan secara digital. Dengan adanya pelatihan ini produsen kopi teh pelawan dan gula kabung dapat menggunakan aplikasi facebook, marketplace, dan instagram untuk melakukan promosi dengan mudah dan produk yang telah dibuat dapat dikenal oleh masyarakat luas sehingga sangat memudahkan dalam proses penjualannya. Adapun indikator tercapainya tujuan dan tolak ukur keberhasilan pelatihan adalah sebagai berikut:

Tabel 1. Indikator Tercapainya Tujuan dan Tolak Ukur Keberhasilan Pelatihan

\begin{tabular}{|l|l|l|}
\hline \multicolumn{2}{|c|}{ Tujuan } & \multicolumn{2}{|c|}{ Indikator Ketercapaian } & \multicolumn{1}{|c|}{ Tolak Ukur } \\
\hline Memberikan pelatihan & Pemahaman terhadap & Mampu membuat akun media \\
penggunaan media sosial & langkah-langkah pemasaran & sosial dan memasarkan \\
facebook dan instagram & produk melalui media sosial & produk melalui media sosial \\
dalam memasarkan produk & facebook dan instagram & tersebut \\
\cline { 3 - 3 } Memberikan pelatihan & Pemahaman dan pelaksanaan & Mampu menerapkan strategi \\
pengelolaan akun media & strategi dalam mengelola & dalam mengelola akun sosial \\
sosial yang telah dibuat serta & akun media sosial dalam & media secara efektif dan \\
strategi dalam memasarkan & memasarkan produk & \\
\hline
\end{tabular}


produk

Kegiatan pelatihan dilakukan dalam dua sesi yakni sesi pertama berkaitan dengan materi tentang pemasaran digital yang menggunakan facebook dan instagram. Pemasaran digital adalah suatu usaha untuk mempromosikan sebuah merek dengan menggunakan media digital yang dapat menjangkau konsumen secara tepat waktu, pribadi, dan relevan. Facebook adalah sebuah layanan internet media sosial yang mengacu ke interaksi antara orang lain, dan tidak hanya itu, facebook juga menyediakan marketplace yang bisa digunakan dengan mudah oleh orang-orang. Marketplace adalah suatu alat media sosial yang digunakan untuk tempat menjual dan membeli suatu produk bekas ataupun produk baru, serta bertindak sebagai pihak ketiga sebagai transaksi online. Instagram adalah sebuah aplikasi berbagai foto dan video yang memungkinkan pengguna mengambil foto dan video serta menerapkan filter digital lalu membagikannya keberbagai layanan jejaring sosial.

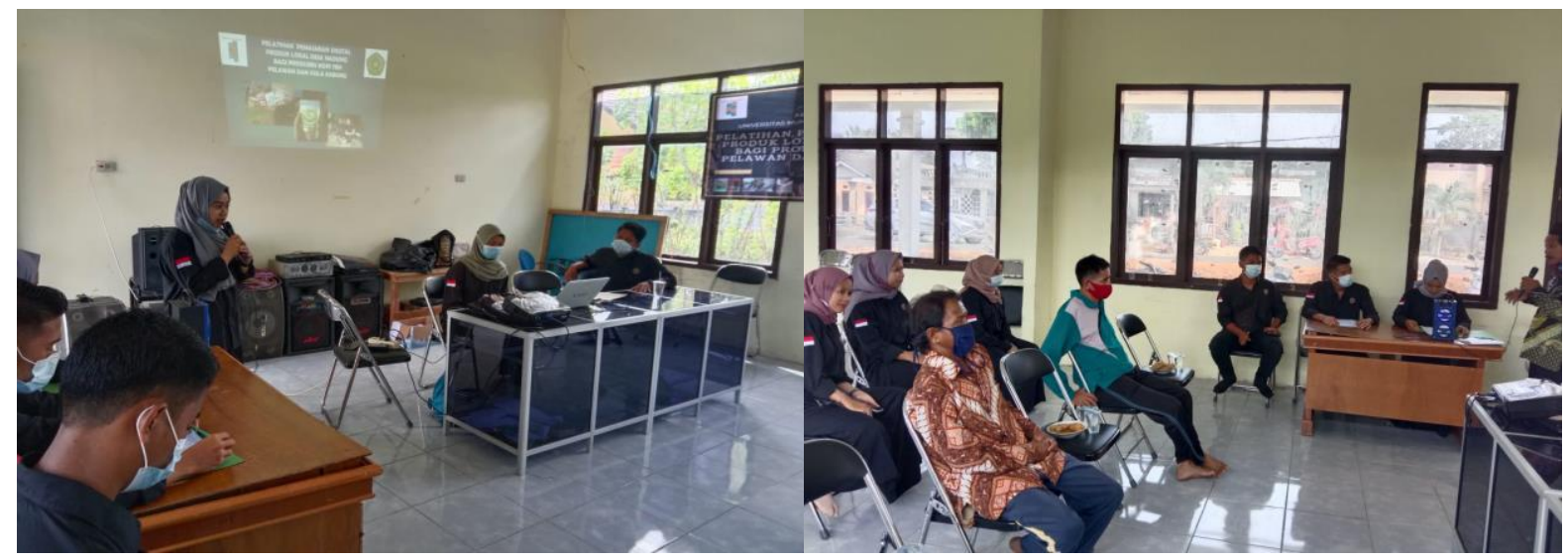

Gambar 1. Penyampaian Materi Pelatihan

Sesi kedua yakni melakukan praktik secara langsung. Para produsen kopi teh pelawan dan gula kabung melakukan praktik secara langsung dengan menggunakan facebook dengan fitur marketplace dan instagram. Akan tetapi ada beberapa kesulitan yang dialami oleh produsen saat pelaksanaan pelatihan berlangsung yakni tidak adanya alat komunikasi seperti gawai dan laptop sehingga peserta tidak bisa mempraktikkannya secara langsung. Jaringan internet yang kurang stabil juga menghambat praktik memasarkan produk secara digital.

Sesi kedua dilanjutkan dengan praktik memasarkan produk terkait dengan bagaimana cara mengelola dan memasarkan produk melalui facebook dan instagram. Dalam pemasaran digital menggunakan facebook hal pertama yang dilakukan yakni membuka alamat facebook 
dengan akun yang telah ada dan memastikannya terhubung dengan jaringan internet. Langkah Selanjutnya yakni masuk ke menu marketplace, lalu tekan OK. Setelah muncul tampilan kemudian klik tulisan "jual barang”, kemudian lanjutkan dengan mengeklik "barang dijual. Setelah selesai maka akan muncul tampilan gambar produk yang akan di jual, serta mengisi judul, harga, kategori, kondisi, merek, dan klik "selanjutnya". Langkah terakhir yang dilakukan yaitu memilih alamat yang ingin diterbitkan. Setelah diterbitkan maka barang yang ingin dijual akan muncul di marketplace.

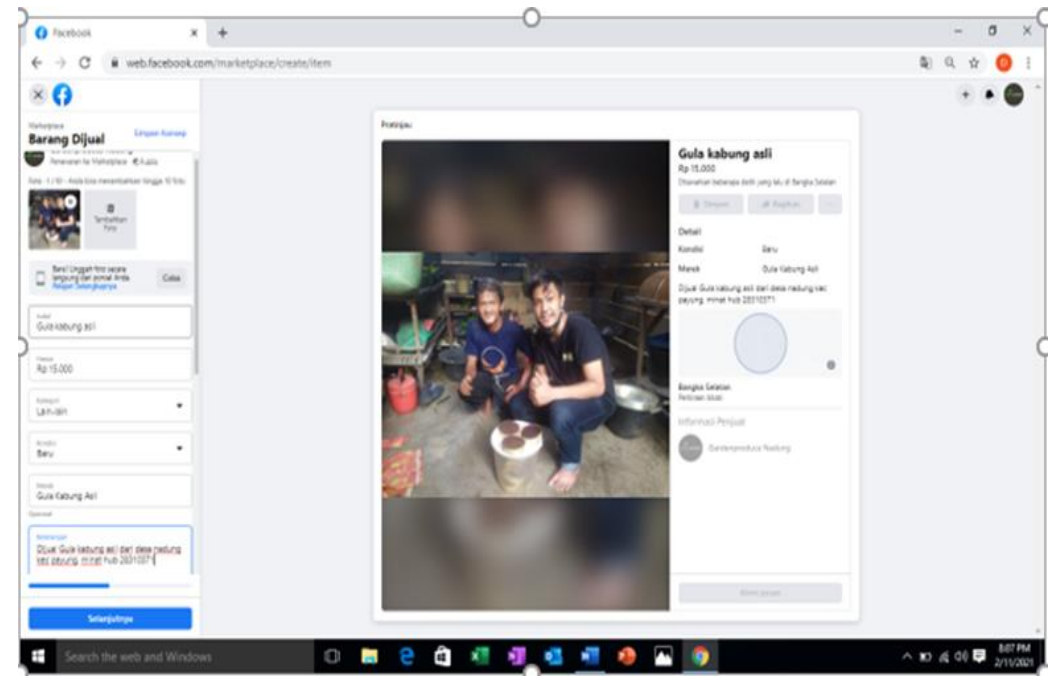

Gambar 2. Tampilan Fitur Marketplace di Facebook

Selanjutnya pemasaran digital menggunakan instagram langkah pertama yang dilakukan yaitu kita harus mempunyai akun terlebih dahulu, kemudian mengisi kolom kosong yang telah tersedia. Tahap selanjutnya yakni isi email dan password yang telah dimiliki, lalu klik login. Setelah masuk ke akun instagram, kemudian klik segi empat yang ada dibawah untuk menampilkan gambar barang yang akan di jual. Setelah memilih gambar barang yang ingin diunggah kemudian klik "selanjutnya" guna untuk mengisi keterangan yang ingin ditulis sesuai dengan barang yang akan dijual. Langkah terakhir yakni klik bagikan, yang berarti bahwa produsen telah membagikan hasil postingan berupa barang yang di jual. 

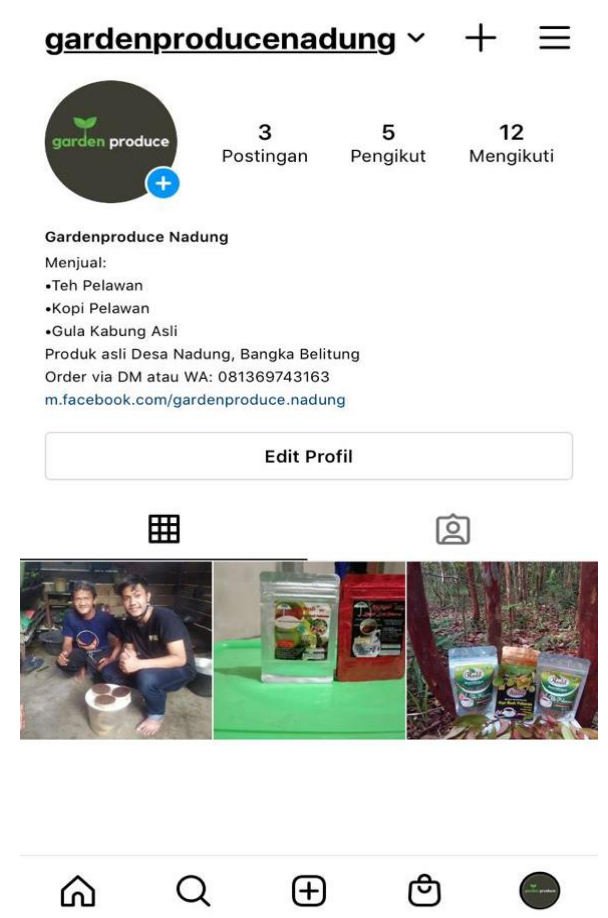

Gambar 3. Tampilan Feed Instagram

Pada sesi terakhir ini menunjukkan adanya peningkatan pengetahuan dan pemahaman peserta pelatihan yang ditandai dengan nilai jawaban post-test mengalami peningkatan jika dibandingkan dengan hasil pre-test yang disajikan sebagai berikut.

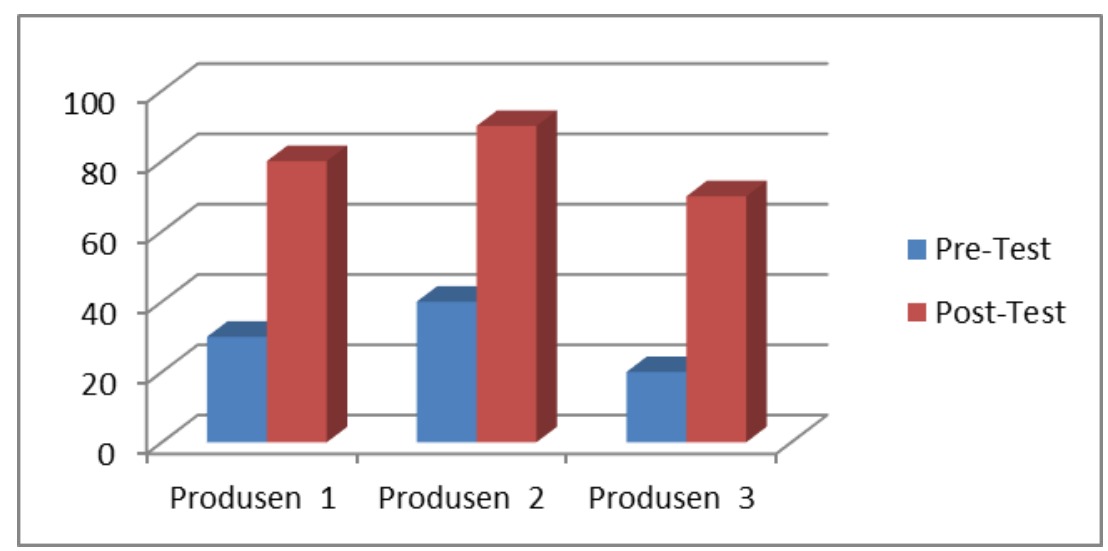

Gambar 4. Perbandingan Hasil Pre-Test dan Post-Test

Berdasarkan pelatihan yang telah dilaksanakan selama satu hari dengan metode pelatihan yang telah diterapkan, hasil post-test yang didapat jika dibandingkan hasil dengan hasil pre-test mengalami peningkatan yang signifikan. Hal tersebut menunjukkan adanya 
peningkatan pengetahuan dan pemahaman peserta pemasaran digital melalui aplikasi facebook dan instagram. Dengan memiliki akun media pemasaran online secara mandiri dan dibekali dengan pelatihan yang telah dilaksanakan, diharapkan produsen kopi teh pelawan dan gula kabung mampu melakukan pemasaran secara digital dengan mudah dan melakukan transaksi produk ataupun jasa yang dimilikinya tanpa terbatas lokasi dan waktu.

\section{KESIMPULAN}

Berdasarkan pembahasan mengenai pelatihan pemasaran digital produk Desa Nadung: kopi teh pelawan dan gula kabung, maka disimpulkan sebagai berikut:

1. Pemasaran digital dapat menjadi salah satu alternatif dalam memasarkan produk secara luas dan cepat khususnya bagi produsen kopi teh pelawan dan gula kabung.

2. Peserta pelatihan memahami tahapan pemasaran produk melalui media sosial facebook dan instagram.

3. Peserta pelatihan mampu membuat akun media sosial sendiri untuk memasarkan produk.

4. Peserta pelatihan mampu menerapkan strategi dalam mengelola akun media sosial yang telah dibuat untuk memasarkan produk.

Berdasarkan simpulan di atas, saran yang dapat diberikan sebagai berikut:

1. Menjalin kerja sama dengan pihak lain untuk memasarkan produk.

2. Mengurus label halal daan BPOM bagi produk yang belum memilikinya.

3. Masyarakat diharapkan dapat mengelola media sosial untuk memasarkan produk untuk menjangkau konsumen yang lebih luas.

\section{DAFTAR PUSTAKA}

Castellano, K. E, \& Ho. A. D. 2013. A. Practitioner's Guide to Growth Models. Washington DC: Council of Chief State School Off cers.

Devy, H. A., \& Soemanto, R. B. 2017. Pengembangan Obyek Dan Daya Tarik Wisata Alam Sebagai Daerah Tujuan Wisata Di Kabupaten Karangnya. Jurnal Sosiologi DILEMAH, $32(1), 34-44$

E-Marketer. (2017). Digital Ad Spending in Select Countries in Southeast Asia 2016-2021 di http://www.emarketer.com.adspendtool (diakses tanggal 23 Februari 2021)

Herman sofyandi. Cetakan kedua. 2013. Manajement Sumber Daya Manusia. Yogyakarta: Graha Ilmu. 
Kotler, Philip and Gary Armstrong. 2012. Prinsip-prinsip Pemasaran. Edisi 13. Jilid 1. Jakarta: Erlangga

Kotler, Philip and Kevin Lane Keller. 2012. Marketing Management 12. New Jersey: Pearson Prentice Hall. Inc.

Nadhira Salsabila. (2020). Perubahan yang Terjadi Dalam Masyarakat Sebagai Dampak dari Covid-19. Fakultas Ilmu Sosial dan Ilmu Politik (FISIP). Universitas Brawijaya. http://fisip.ub.ac.id//?p=102827lang=id

Pradiani, Theresia. 2017. 'Pengaruh Sistem Pemasaran Digital Marketing Terhadap Peningkatan Volume Penjualan Hasil Industri Rumahan', Jibeka / Volume 11. Nomor 2, Agustus 2016.

Widodo, Suparno Eko. 2015. Manajemen Pengembangan Sumber Daya Manusia. Jakarta: Pustaka Pelajar. 